\title{
Public Finance in Practice and Theory
}

\author{
Alan J. Auerbach \\ University of California, Berkeley
}

May 2009

This paper was prepared as the Richard Musgrave Lecture, CESifo, Munich, May 25, 2009. I am grateful to Jim Hines, Louis Kaplow and Joel Slemrod for comments on an earlier draft. 


\section{Introduction}

As a former student and colleague of Richard Musgrave, it is a great pleasure for me to deliver this Richard Musgrave Lecture. With his broad perspective and deep understanding of economic theory and institutions, Richard defined the field of public finance as it is understood today, and we are all greatly in his debt.

The title I have chosen transposes two of the words in the title of Richard and Peggy Musgrave's popular textbook, Public Finance in Theory and Practice (1989). My purpose in rearranging the title is twofold. First, I have already used the regular title once before for a previous paper (Auerbach 1993). Though some economists are accused of writing the same paper more than once, even those who are guilty of this practice are wise enough to use different titles when they do so. Second, I wish to place greater emphasis on the practice of public finance and, in particular, the ways in which this practice does not accord well with the standard theories at our disposal.

Public finance has both normative and positive elements, and moving between theory and practice requires attention to help us understand both what policies government should adopt and whether it is likely to do so. We should not be surprised when bad policies are adopted in spite of better policies being available if our political system is structured to deliver bad outcomes, for example, if our political environment gives politicians strong incentives to serve narrow interests at the expense of the common good. But I will focus here on examples where the contrast between normative and positive outcomes is not so clearly explained, and thus where understanding the reasons for observed policy practices might help us develop better positive theories.

It is very tempting for an economist frustrated by the state of public policy simply to conclude that politicians do some of the things they do because they do not understand the 
economic consequences of their actions. Undoubtedly many public policy actions can be attributed to mistakes and misunderstandings. But when the behavior in question is widespread and persists over time in the face of information and discussion of its economic consequences, we should consider alternative explanations.

There is no shortage of puzzling economic policies practiced by national governments around the world, so my list will be selective. I will focus on cases where standard arguments (misalignment of incentives, corruption, rent-seeking, concentration of benefits, imperfect information, etc.) seem insufficient to explain the divergence between positive outcomes and normative prescriptions, and I will draw most heavily on examples from the United States, with which I am naturally most familiar. For each of the examples on my list, I will discuss the current public policy practice. After presenting my examples I will consider how our positive and normative theories may need to be expanded to understand why things are the way they are, and the lessons we might take for the practice and theory of public finance.

\section{Piecemeal Progressivity}

Who should bear a society's fiscal burdens? Most advanced economies have determined that the most equitable approach is a progressive distribution, by which we mean that those with a higher ability to pay, as measured, for example, by income (or consumption, or wealth) should pay a greater share of their before-tax income than those with a lower ability to pay. How progressive the burden should be, and whether the focus of progressivity should be throughout the income distribution or primarily among the poorest, are reasonable questions for which there is no simple "right" answer. But what is clearer (or at least seems clearer before we confront actual practice) is that what matters is the overall progressivity of the fiscal system. With many instruments of tax, transfer and spending policy at its disposal, the government can achieve a given degree of progressivity in many ways. As some 
instruments will be better suited to achieving progressivity than others, it makes sense that the government would utilize those instruments for equity.

As a rule, it is easiest to achieve progressivity using instruments that rely on individual characteristics related to the objective. Most simply, we can use a progressive income tax to achieve a progressive outcome if we wish to place a higher relative burden on higher-income individuals. We may do better still by augmenting our system with instruments based on other characteristics that relate to ability to pay, such as having a disability, being elderly, or having children. ${ }^{1}$

By contrast to these direct taxes and transfers, based on individual characteristics, systems of indirect taxation that are transaction-based are much more difficult to make progressive, because, as the category name suggests, they relate only indirectly to individuals: our objective is progressivity with respect to individuals, not the transactions in which they engage. For example, to achieve progressivity under a value-added tax (VAT), we must determine which goods and services are relatively concentrated among the poor, such as food, and tax these commodities less heavily than others, while at the same time imposing an unusually heavy tax on items preferred by the rich, such as yachts, jewelry, furs and luxury automobiles. The problem with varying VAT rates in this way, though, is that because we are subsidizing food rather than food purchased by the poor, most of the food subsidy goes to the non-poor. Thus, we would need huge variations in tax rates among commodities to effect much redistribution, which even so would be limited, ${ }^{2}$ and in so doing we would produce massive distortions in the purchasing decisions of households, rich and poor alike.

\footnotetext{
${ }^{1}$ The classic references here are Atkinson and Stiglitz (1976) on the general superiority of direct taxation and Akerlof (1978) on the use of "tagging" based on individual characteristics. There are, of course, many subtleties and qualifications to the results that I do not go into here, which lead to exceptions to the general results. But these exceptions cannot be used to explain or rationalize the general and widespread practices discussed here.

${ }^{2}$ See Sah (1983).
} 
In short, if we have a progressive direct tax at our disposal, there is a very convincing argument for using that tax, perhaps in conjunction with other programs based on observable individual characteristics, as our main vehicle for achieving progressivity. And yet, it is standard practice for indirect taxes to reflect the desire to achieve progressivity in their design. Value-added taxes around the world commonly exempt or tax at a reduced rate food and other necessities. ${ }^{3}$ The same practice is observed for the sales taxes imposed by individual states in the United States. Even though there is no sales tax or VAT at the U.S. national level as yet, we have had an important national episode of attempting to use indirect taxes explicitly for distributional purposes. In 1990, President George H. W. Bush and Congress agreed to introduce a new set of excise taxes on specific luxury goods, indeed on those same goods mentioned above (yachts, jewelry, furs and luxury automobiles) as well as personal-use private aircraft. ${ }^{4}$

This observed practice of what one might call "piecemeal progressivity" is also observed in the administration of some government spending programs, as discussed further below. Its influence is seen even in the law, where a widely-held view suggests that there is a role for the setting of legal rules in part on the basis of distributive objectives. For example, if those likely to cause damage in a particular context are wealthier than those suffering the damage, then one might assess higher transfers from the violator to the victim, or to the state, than the actual damage caused, in order to further distributive objectives. As in the case of indirect taxation, one can argue for using other, more effective instruments to achieve distributional objectives, leaving legal rules to be designed to promote efficient outcomes that

\footnotetext{
${ }^{3}$ See, for instance, European Union (2009).

${ }^{4}$ Starting in 1991, a 10 percent luxury tax was levied on amounts exceeding the respective thresholds for cars valued above $\$ 30,000$, boats above $\$ 100,000$, jewelry and furs above $\$ 10,000$ and private planes above $\$ 250,000$. The provisions were gradually repealed over the next several years and were completely gone by the end of 2002.
} 
relate penalties to the damage caused. ${ }^{5}$ Yet, even in societies with progressive taxation, the shaping of legal rules for redistribution retains its appeal. Perhaps the most remarkable illustration of this practice is the system of speeding fines in Finland, which are based not only on the severity of the offense but also on the violator's income. This system has resulted in fines as high as $€ 170,000$ for a single speeding violation, an amount clearly in excess of the social damage imposed by speeding. ${ }^{6}$

What drives the design of the VAT, U.S. luxury taxes, and other policies such as legal rules to incorporate the objective of progressivity when other methods exist and are already in use that are evidently better structured for achieving progressivity? We can start by discarding a common wrong answer, that to make the income tax more progressive would require such high marginal tax rates that the economic distortions would be unacceptable, so that using other instruments is preferred. This answer is wrong because the other instruments impose the same economic distortions as the income tax, plus others in addition. It does not matter if taxes lower my income or raise the price of the things I buy, and raising the prices of some things I buy and lowering the prices of others introduces another set of economic distortions, to my choices among the things I purchase.

A related argument is that overall tax enforcement might be enhanced by relying on several taxes rather than just one. But this argument, even if it is correct, applies to the revenue we collect from taxes, not their contribution to overall progressivity, and the two do not have to change together. For example, we might lower income taxes and raise indirect

\footnotetext{
${ }^{5}$ See Kaplow and Shavell (1994).

${ }^{6}$ This fine was levied in 2004 to the heir to a family-owned sausage empire, who was caught driving $80 \mathrm{~km} / \mathrm{hr}$ in a $40 \mathrm{~km} / \mathrm{hr}$ zone. That fine exceeded the level of $€ 116,000$ previously assessed to a Nokia executive, although that executive's fine was later reduced substantially due to his drop in income following a downturn in the mobile phone industry. See http://news.bbc.co.uk/1/hi/business/3477285.stm . Below, I consider an alternative possible explanation for this particular practice.
} 
taxes while still relying entirely on the income tax to provide a given degree of progressivity, by making the remaining income tax even more progressive. ${ }^{7}$

Perhaps the most common justification for piecemeal progressivity is that while using the income tax might be preferred, this is not politically possible and so other means, even if inferior in nature, must be used. But this argument essentially assumes the conclusion, for it fails to explain why a society would force itself to use one method to achieve an objective when another, superior method is available. This is not an issue of some groups gaining at the expense of others as a result of using the inferior method, since we are, roughly, collecting taxes from the same individuals, but in a less efficient manner.

Some insight into this puzzle might be gained from the 1990 U.S. luxury tax experience. When President Bush and Congress introduced luxury taxes, they did so while also increasing the marginal income tax rate on the highest income individuals from 28 percent to 31 percent. Already under pressure for reneging on his famous 1988 campaign pledge, "read my lips: no new taxes," President Bush would have had to accept even higher increases in the top marginal income tax rate to produce the same revenue and the same estimated tax burden distribution without relying on the luxury taxes. Introducing the tax increase in pieces, therefore, may have been viewed as a way of hiding the total increase in effective marginal tax rates at the top.

Note that a generally different approach was taken by the Tax Reform Act of 1986, which was designed to maintain the existing degree of progressivity by balancing reduced marginal income tax rates with other changes in tax provisions that increased tax burdens. In 1986, the effects of provisions taken together were emphasized, rather than hidden. Even in 1986, however, the effects of some provisions were presented separately. In particular, the

\footnotetext{
${ }^{7}$ Indeed, one such recent proposal would do this in the United States, eliminating income taxes for most households and lowering income taxes for those with high income, replacing the lost revenue with a broad-based value added tax. See Graetz (2008).
} 
corporate tax increases used to finance individual income tax cuts were commonly left out of presentations of the legislation's distributional effects, perhaps hiding a progressive shift in the tax burden. ${ }^{8}$

The lesson from the U.S. experiences of 1986 and 1990, then, may be that politicians seek to obfuscate distributional effects of tax changes when these changes lead to increased progressivity. Or perhaps the lesson is that politicians do this when they wish to hide the results from their supporters, as might have been the case for the Republican presidents in 1986 and 1990. But how well hidden can the results have been when they were contained in the same piece of legislation and highly publicized? Much has been written recently about the salience of taxation potentially having an impact on individual decisions, ${ }^{9}$ although we have little evidence regarding the effects of provisions on such a grand scale, or about whether the salience of tax provisions changes over time. Can individuals who have been subject to the VAT for their entire lives still fail to comprehend that progressivity achieved through the VAT is a substitute for progressivity achieved through the income tax? And why would the attempted obfuscation take the form of understating progressivity, rather than overstating it? One could argue, I suppose, that politicians are seeking to produce a just society without alienating those who can exert a powerful role in election outcomes, but one could just as easily imagine a world in which politicians make hidden transfers to the powerful to ensure their continued support, producing a tax system that is less progressive than might be apparent. $^{10}$

Finally, it might simply be the case that individuals are naturally disposed to thinking about government policies individually, so that an apparently regressive tax seems unfair, even if it is part of an overall fiscal system with a suitable degree of progressivity, and

\footnotetext{
${ }^{8}$ See Auerbach and Slemrod (1997).

${ }^{9}$ See, e.g., Chetty, Looney and Kroft (2007).

${ }^{10}$ See, e.g., Coate and Morris (1995).
} 
income-based speeding fines seem fair, even if they provide much distorted incentives to those who drive. ${ }^{11}$

In summary, though the economic arguments against doing so are compelling, piecemeal achievement of a progressive distribution of the fiscal burden is a standard feature of national fiscal systems. Why this occurs is still something of a mystery if we use our standard theoretical tools for analysis.

\section{Minimum Taxes and Other Individual Limits}

The theory of public finance suggests that we should decide on a desired tax base and rate structure and then impose taxes accordingly. But tax codes are filled with additional provisions that seem to reflect ambivalence on the part of tax authorities. While the main provisions of a tax code may specify that a particular type of income is taxable, or that a particular expense is deductible, other provisions override these general principles in particular circumstances in a manner that typically makes tax systems much more complicated. Among the restrictions of this type that are very common around the world are those that limit deductions for tax losses and interest. Both deductions would be appropriate under the principles of standard income tax design, but one is unlikely to find any tax system that offers unlimited deductions for losses and interest.

In many or perhaps most instances, however, limits on deductions for losses and interest can be rationalized as a tool for overcoming some other defect in the tax system that may be difficult to address directly. In the case of losses, for example, tax authorities may be concerned that a business showing a large loss is more likely to be engaged in fraud than a business reporting income. If fraud is hard to detect, then limiting deduction for losses represents an alternative, even if a very imperfect one that also discourages risk-taking, as we

\footnotetext{
${ }^{11}$ Indeed, some experimental evidence suggests that individuals do think separately about components of the tax system. See McCaffery and Baron (2003).
} 
have understood since the work of Domar and Musgrave (1944). Indeed, tax systems commonly allow losses to be offset against previous or future income, attempting to cushion the impact on legitimate firms. For individual taxpayers, limits on the deduction of capital losses is necessitated by taxation of capital gains only on realization, which gives taxpayers the opportunity to realize losses and hold gains.

Likewise, some limits on interest deductions are aimed at restricting other undesired behavior. Under so-called "thin capitalization" rules, for example, which limit interest deductions based on the share of debt in a local subsidiary's capital structure, countries seek to prevent multinational companies from using unlimited interest deductions to shift profits generated locally to tax haven countries with low tax rates.

But there are other limits imposed on the basic income tax structure that are more difficult to rationalize. Perhaps the most significant of these is the "minimum tax," so named because it is designed to establish some minimum tax liability for taxpayers who otherwise would owe little or no tax. The United States imposes minimum taxes in conjunction with both the individual and corporate income taxes. The basic approach of the minimum tax is to apply a lower tax rate schedule than the regular income tax to a broader tax base that includes more income and permits fewer deductions, so that taxpayers who have relatively high levels of such included income and excluded deductions will face a higher tax liability under the minimum tax, even with its lower tax rates, than under the regular income tax. Under the U.S. individual minimum tax, for example, taxes paid to state and local governments are not deductible, whereas they are deductible to a considerable extent under the regular income tax, so that taxpayers with high state and local tax liabilities are more likely to be subject to the minimum tax.

The origins of the minimum tax tell us something about the motivation behind it. The U.S. minimum tax was introduced by the Tax Reform Act of 1969, following the disclosure 
by the government that many very high-income individuals had paid no income tax at all through combination of non-taxable income and substantial tax deductions. At first, the minimum tax affected only around 20,000 taxpayers per year and accounted for little revenue. But in recent years, the individual minimum tax has affected around 4 million taxpayers, and its added tax liabilities have accounted for 4 percent of all income tax revenues. ${ }^{12}$

Thus, the minimum tax was introduced as a small measure to deal with outrage about the apparent unfairness of the tax system, but it has become much more important over the years. Unlike in the examples given above relating to limits on losses and interest deductions, however, there is no issue here of the government being unable to address the perceived problem more directly. For example, if the deduction of state and local taxes is seen as inappropriate, the government is fully able to curtail such deductions under the regular income tax. The original minimum tax may have been justified as a cosmetic measure, the government believing that the tax system as structured was appropriate but needing to deal with public perceptions that it was not. But the current minimum tax is much more than a cosmetic measure, so why does it still exist?

Common explanations offered in the United States provide little real insight on this question. Some suggest that it would be difficult to find additional revenue to replace what would be lost by repeal of the minimum tax, but this argument could be used to explain why any tax remains in place and fails to explain why any tax would ever be reduced or repealed. In recent years, others have argued that the minimum tax promoted the objectives of Republicans, because the states with the highest state and local tax burdens (and hence having taxpayers more likely to be subject to the minimum tax) all leaned toward Democrats. But this reasoning fails to explain the durability of the minimum tax through periods of national control by Democrats as well as Republicans.

\footnotetext{
${ }^{12}$ These numbers are provided by the Tax Policy Center (http://www.taxpolicycenter.org/).
} 
In short, the philosophy behind the minimum tax, as currently structured, seems to be that it is acceptable to reduce one's taxes to a certain extent through straightforward arrangements laid out in the tax code, but that limits should be placed on the ability of any single individual to engage in such tax-favored behavior. These limits have their economic costs, because they distort the allocation of activities among individuals. For example, some of the deductions disallowed under the minimum tax are for costs associated with natural resource extraction, so taxpayers are discouraged from concentrating too much individually in such sectors. Placing limits on each individual can also lead to a reduction in the overall amount of the activity that takes place. But if such an overall reduction is the policy's underlying objective, it could be accomplished more efficiently by reducing the tax benefits uniformly, for example by reducing the fraction of expenses that are deductible.

Lest one think that the minimum tax is just an inexplicable historical accident, one can find instances of similar provisions elsewhere in U.S. policy. Perhaps the most important is the U.S. system of agricultural support payments to farmers of various crops. Under this system, there have been limitations in place since the Agricultural Act of 1970. These limits, as most recently amended by the 2008 Farm Bill, take the form of ceilings on the size of payments that any individual farmer can receive. It is noteworthy that the payments are also subject to an income limit, with farmers having income above the specified limit (now $\$ 750,000$ per year) not eligible to receive any payments. Thus, the system of agricultural support payments reflects both of the anomalies discussed so far, individual limits on the receipt of government tax or spending benefits, and the use of government programs other than the system of direct taxation to achieve distributional objectives.

Thus, one might justify some of the limits placed on individuals and firms in their use of tax benefits as accomplishing objectives that are administratively difficult to approach more directly. But this is not so of the minimum tax, nor is it the case for agricultural support 
payments. It may be that these tax and spending benefits exceed those that are socially desirable, and that the limits placed on individuals in their use serves the purpose of limiting overall take-up as well. But the logic of this approach presumes that directly attacking the overall level of activity is more difficult to achieve, politically if not for other reasons. Perhaps only through the guise of placing limits on individuals can the government achieve such overall limits.

And why would placing limits on individuals seem attractive? If citizens think of the progressivity of programs individually rather than on an integrated basis, as suggested above as a possible explanation for the practice of piecemeal progressivity, then placing limits on individual access to tax deductions or spending benefits may also be viewed as furthering the objective of progressivity. Thus, the two types of anomalies we have explored thus farpiecemeal progressivity and individual limits - may be closely linked, and not simply because in both cases the government may be trading economic efficiency for reduced perception of its ultimate objectives.

\section{Quantity-Based Restrictions}

Countries around the world struggling to develop policies to counteract global warming have devoted renewed attention to alternative tax-based and quantity-based mechanisms for limiting particular activities, in this instance the emissions of greenhouse gases. Quantity-based approaches are typically based on the use of tradable permits, while tax-based approaches rely on taxes placed on emissions.

As is well understood, these two approaches are closely related, in that one can determine market equilibrium by setting either the price or the quantity and letting the other respond. Indeed, if tradable permits are auctioned off, then the government will receive the same revenue, emissions will be the same, and producers and consumers will face the same 
prices, as in the case where the government levies a tax on emissions sufficiently high to produce the same level of emissions. There are, of course, subtle differences between controlling quantities and controlling prices when there is uncertainty regarding market responses or imperfect competition among producers. But a major potential difference between these two approaches is revenue, should the tradable permits be given away rather than sold by the government. The advantage of raising revenue through corrective taxes or permit auctions has been central to discussions of the so-called "double-dividend" hypothesis, which notes that funds so raised can be used to reduce other taxes.

Given that tradable permits and emissions taxes can be used to implement the same underlying policies, one might ask why the permit approach has gained such prominence given the long-standing existence of taxes on certain pollutants, such as motor fuels. An answer sometimes offered is that the tax effectuated when tradable permits must be purchased is an implicit one. This answer is not very convincing if all of the permits are first auctioned off by the government, for then the payments for permits and payment of taxes involve essentially identical transactions. On the other hand, if the government wishes to give away at least some of the permits, then this approach may be easier politically, especially if the recipients are industrial polluters, than making transfer payments of the same value to the same recipients, as would be required to produce the same outcome under an emissions tax. This leaves aside the question of whether and to whom compensation should be paid when the revenue could instead be used to reduce other taxes.

But beyond the issue of compensation, there are other policy choices that are more difficult to justify, such as restrictions on the trading of rights to pollute. For example, the United States has since 1975 imposed Corporate Average Fuel Economy (CAFE) regulations on automobile manufacturers to increase the average miles per gallon of gasoline for the average automobile sold by each manufacturer. (Other countries impose similar rules that are 
even more restrictive.) Leaving aside the fact that regulating fuel economy is a very

imperfect way to regulate emissions (which depend not only on fuel efficiency but also on the intensity of driving) another problem with CAFE standards is that they are not tradable. Thus, it is not permissible for one manufacturer that makes small cars or is very adept at making cars fuel efficient to sell unused "CAFE credits" to another manufacturer facing higher costs of meeting the uniform standard. The consequence is an increase in the total cost incurred by manufacturers as a group to meet the CAFE standard. Unlike on the issue of whether to pay compensation, where lobbying by one group might explain the outcome, there are no obvious winners from the policy of not allowing trade. Why, then, are the quotas assessed on individual firms not tradable?

Here, we again confront a case where practice goes beyond our theory. One possible explanation is that there is, among many observers, revulsion to the idea of allowing the purchase of a right to engage in an activity that is viewed as socially undesirable. Allowing purchase of the right to pollute, so the argument goes, implies that pollution is acceptable and that those individuals or countries with greater resources can shift their moral responsibilities for reducing pollution onto others. ${ }^{13}$

Of course, any standard that does not eliminate pollution entirely implies the judgment that pollution is acceptable, but the perception of fairness and justice here goes beyond such logic. It is also not clear that the same objections would be raised to the imposition of a tax on emissions, even though as already discussed such a tax would result in essentially the same outcome as the auction of tradable permits. Paying for the right to pollute and paying the same amount in the form of a tax on pollution may be equivalent economically but not necessarily in the eyes of some observers.

\footnotetext{
${ }^{13}$ See, for example, the Op-Ed essay by Michael J. Sandel, a Professor of Government at Harvard, in the New York Times, "It's Immoral to Buy the Right to Pollute," Dec. 15, 1997, which criticized the Clinton administration's position favoring pollution trading rights at the Kyoto conference on global warming. It is notable, however, that many environmentalists have a much more favorable view of permit trading.
} 
This perspective regarding the morality of purchasing the right to engage in socially undesirable activities may also help us understand Finland's approach to speeding fines. Such fines may not simply be viewed as another tool for redistribution, as suggested above, but may also be perceived as a fair way of preventing wealthy individuals from "purchasing" a disproportionate share of the "speeding rights" from those with lower income for whom a uniform fine would be more difficult to pay. That is, even if it is efficient for wealthy individuals to speed more frequently, some may perceive this as intrinsically unfair.

Another striking anomaly regarding the choice between tax-based and quantity-based restrictions comes from the area of international trade policy, where import tariffs and import quotas are the relevant policy instruments. As in the pollution-control context, the two instruments are basically equivalent if the quotas are auctioned off and then tradable, but in the trade context it is rare to observe the sale of quotas, at least explicitly (i.e., leaving aside bribes and other payments made to obtain them). This is the case even though the transfer via the free grant of a quota goes to a foreign producer, presumably with less political influence than a domestic one.

Of course, imposition of either tariffs or quotas imposes social costs from forgoing gains from trade, but a country might be enticed to adopt these trade restrictions nonetheless, either to improve terms of trade, thereby making its residents better off at the expense of the rest of the world, or simply to help some of its residents at the expense of others by protecting certain domestic industries. Thus, it is not hard to understand why countries might and do erect trade barriers. But why they would use quotas, thus granting rather than selling "quota rents" to foreign producers, requires further consideration, particularly given that these rents are not small. For example, one compilation ${ }^{14}$ of estimates put the quota rents from major U.S. trade restrictions (on automobiles, dairy products, steel, sugar and textiles) at between $\$ 7$

\footnotetext{
${ }^{14}$ Feenstra (1992).
} 
billion and $\$ 17$ billion around 1985, around 1 to 2 percent of federal revenues or 12 to 28

percent of corporate tax revenues, and of a magnitude similar to actual tariff revenues $(\$ 12.2$ billion in 1985, according to the Bureau of Economic Analysis.)

It is hard to think of an explanation for this gift to foreigners that does not involve differences in perceptions about the two policies on the part of domestic residents. Whereas tariffs, as taxes, might be seen as contributing to an increase in prices, at least of imported goods, the impact of quotas might be harder for some to comprehend, particularly when such quotas are "voluntary," as was the case for the U.S. automobile quotas imposed on Japanese producers in 1981. Making quotas marketable could clarify the close relationship of quotas and tariffs and, in doing so, make domestic consumers more aware of the losses they suffer as a result of the policy. Thus, once again, government might be willing to accept additional social losses in furtherance of a policy objective, in this case the protection of certain industries or a terms-of-trade improvement rather than the achievement of a more progressive fiscal system. As this case suggests, however, the government's ability to confuse voters may contribute to greater policy flexibility without contributing to better fiscal policy.

In summary, tax-based and quantity-based methods for controlling activities are very similar in nature but are applied differently in practice. Two particular elements of common practice that are difficult to square with the basic theory of public finance are limits on the ability to trade quotas and the granting of import quotas without compensation, both practices that harm domestic residents as a whole without providing appreciable benefits to any particular group. It is conceivable that an expanded view of fairness might help explain the former and that the latter might derive from a desire on the part of policy makers to mask the effects of restrictive trade policies on prices. 


\section{Dedicated Taxes}

In general, the sources and uses of government funds need not be related. If a public spending project, a transfer program, or a tax incentive needs to be financed, then we might wish to take the distributional effects of the program into account when deciding who should bear the burden of taxation, but there is no need to specify where the revenue comes from, given that money is fungible.

There are, of course, particular cases in which it makes sense to tie taxes and spending together, as in a public pension or unemployment compensation program, where the benefits received are related to the taxes paid, or at least to the earnings on which the taxes are based. Then, tying taxes to spending can establish a link between benefits received and taxes paid, and so may lessen the perceived burden of the taxes.

In many cases of such apparent linkage, however, the actual relationship between taxes and benefits at the individual level is weak or nonexistent. For example, the U.S. oldage pension system - Social Security - is financed primarily by payroll taxes on workers, and the benefits that accrue are based on the earnings that are subject to the payroll tax. But the formula used to calculate benefits incorporates so many transfers, from single individuals to married couples, from high-income workers to low-income workers, from young workers to older workers, and from future retirees to current retirees, that the actual linkage between taxes and benefits at the individual level is weak. ${ }^{15}$

In other cases where there are dedicated taxes, the linkage between spending and taxes is essentially nonexistent at the individual level even if the spending and taxes bear some intuitive connection. One example is U.S. federal gasoline taxes, which are earmarked for a highway trust fund used to finance road construction. Though the relationship of gasoline taxes and highway spending may have some logic, the number and quality of roads on which

\footnotetext{
${ }^{15}$ See, for example, the calculations by Feldstein and Samwick (1992).
} 
any individual can drive are unrelated to the gasoline taxes that individual pays. Furthermore, there is no requirement that highway trust fund accumulations actually be spent on highway construction over any specified period. ${ }^{16}$ Another example comes from the U.S. Medicare system, which provides medical care for the elderly. One component of that system, hospital insurance, is financed through a 2.9 percent payroll tax. One does need to have been a worker to qualify for Medicare, so there is some connection between taxes and benefits. But once qualified, the health care one receives is in no way related to the payroll taxes one has paid. A third example comes from President Obama's recent budget, which would institute a new cap and trade system for greenhouse gas emissions and explicitly dedicate a portion of the revenues - $\$ 15$ billion per year - to the development of clean energy technologies. ${ }^{17}$ While both sources and uses of funds go toward reducing pollution, there is no reason to think that the appropriate level of spending on new technology is related to the level of payments by polluters.

Finally, there are some cases where dedicated taxes bear no relationship at all to the expenditures to which they are committed. A nice illustration comes from the practice of direct democracy under the California proposition system. In November 2004, California voters approved Proposition 63, also known as the "Mental Health Services Act." Proposition 63 provides state funding for certain new or expanded mental health programs through a personal income tax surcharge of 1 percent on a taxpayer's income in excess of $\$ 1$ million. (There has, of course, been a long-running dispute since the days of Fitzgerald and Hemingway as to whether the rich are really different, but the dispute has not centered on whether they suffer a higher incidence of mental illness.) And, at the U.S. national level,

\footnotetext{
${ }^{16}$ Indeed, the highway trust fund for many years accumulated surpluses. Another example of overfunding is the delightfully named LUST trust fund, which relies on dedicated motor fuels taxes to fund remediation of Leaking Underground Storage Tanks. See Hines (2007).

${ }^{17}$ See U.S. Office of Management and Budget (2009), Table S-2.
} 
there have been frequent discussions of introducing a value-added tax and dedicating it to the provision of universal health care.

Thus, although dedicated taxes can sometimes act as user fees, we see them in many more instances where such a mechanism is either imperfect or nonexistent. And where there is no natural linkage of taxes and benefits, there can be real economic costs to reliance on dedicated taxes. We may end up relying too heavily on some taxes than others, thereby reducing the tax system's efficiency, and our mix and level of public spending may be distorted by the connections of particular types of spending to specific sources of funding. Why, for example, should California's spending on mental health services rise and fall with the incomes of millionaires? Further, if the practice of tax dedication becomes widespread, the ability of government to shift funds among different categories of spending as circumstances change is limited.

What might explain this common phenomenon of tax dedication? One possibility is that tying taxes to spending helps to overcome taxpayer skepticism. For example, taxpayers might be more willing to pay taxes if they perceive that these taxes are spent on something that they value, even if there is no tax-benefit linkage at the individual level. Tying taxes to spending programs that can be seen as related increases the chance that taxpayers will perceive such value, as in the case of gasoline taxes being used to finance highway construction. This might mean, of course, that spending programs for which related taxes are more difficult to identify may suffer.

A second objective of tax dedication might be either to protect or to limit the amount of a particular type of spending. Those who introduced California's Proposition 63 succeeded in placing a claim on a specific source of revenue, thereby helping to insulate mental health spending from the normal budget process in which this spending would have to compete with other potential uses of funds. On the other hand, one of the reasons advanced for providing a 
dedicated source of revenue such as the VAT for health care has been to try to force health spending growth to conform to the growth of VAT revenues. In either case, though, the influence of tax dedication on funding need not go in the right direction from a social perspective.

Third, tax dedication, particularly where there is some tax-benefit linkage, may be used to accomplish social objectives. Wilbur Cohen, Secretary of Health, Education and Welfare under President Lyndon Johnson and one of the important architects of U.S. social insurance programs, was said to have argued that programs for the poor are poor programs. That is, it might be more difficult to maintain a healthy transfer program for the elderly poor than to embed such a program in a universal public pension system with a dedicated tax by making pension payments higher for low-income retirees and lower for high-income retirees than actuarial calculations would dictate. One can see two reasons why the universal program might fare better in the political arena. First, individuals might be confused, thinking that the program is simply a pension system in which retirees receive benefits based solely on their individual tax payments. Second, a universal system creates a natural constituency of support among the elderly and those nearing retirement. ${ }^{18}$ Even those who over an entire lifetime may have contributed far more to the pension system than they receive as retirees will benefit when old from the system's continuation.

In summary, dedicated taxes may serve several purposes other than to act as user fees. While the mechanisms associated with each purpose may be different, all involve altering the level of public spending relative to what would occur in the absence of tax dedication. We have seen one of these mechanisms, voter confusion, in the other examples discussed above. All mechanisms relate to the political process, but not in the simple sense of determining policies by sorting out winners and losers. As with the other fiscal anomalies already

\footnotetext{
${ }^{18}$ See, for example, the model in Tabellini (2000).
} 
discussed, dedicated tax funding has obvious social costs. There are also some potential benefits, at least to some groups in the population, but one can have little assurance that the overall practice provides a net benefit to society as a whole.

\section{Conclusions}

Richard Musgrave contributed much to our understanding of what constitutes good public finance practice, and therefore also what does not. In this paper, I have presented four examples of the practice of public finance that pose challenges for our theories. In each case, the practices exist even though there are potential alternatives that could make society better off without necessarily creating losers, at least among domestic residents. These fiscal anomalies suggest that our theories need to take seriously several factors that may receive too little attention at present.

First, the structure of a particular policy may affect its salience on the part of individuals. Perhaps individuals are less aware of the progressivity of a fiscal system when this progressivity is achieved in pieces rather than with one particular tax instrument. They may not recognize the taxes implicit in import quotas, particularly if those quotas are given away rather than auctioned off. And they may not understand that public pension systems also incorporate progressive redistribution. Most research to date has focused on the salience of tax policies to individuals with respect to their own decisions, but their decisions as voters should also be affected and governments can be expected to take this into account. ${ }^{19}$

Second, individuals may have notions of fairness regarding the regulation of socially harmful activities that conflict with the perspectives economists take. To economists, speeding and polluting are examples of activities where government intervention is needed to get prices right, to make sure that social costs are properly accounted for so that the socially

\footnotetext{
${ }^{19}$ See, for example, the discussion in Krishna and Slemrod (2003).
} 
appropriate amount of the activity occurs and is allocated efficiently across different individuals. To other individuals, there may be no acceptable level of activities that cause social damage, and it is immoral to use a market mechanism to allocate these activities, even if the market mechanism simulates a tax policy that would not be viewed so negatively, and even if the mechanism makes everyone individually better off.

Third, people may be disposed to think about fairness in terms of individual policies, rather than considering the fiscal system as a whole. Thus, they may see it as fair to limit any one person's receipt of a particular tax benefit or agricultural support payment, even if such limits have no other justification. Citizens may insist that the value added tax be progressive, even though the VAT is not a good vehicle for achieving progressivity. And they may think that high-income speeders should be assessed higher fines, even if the income tax already achieves a desirable degree of redistribution. Why they are disposed to think this way, and the extent to which this is an ingrained predisposition, is not clear.

Fourth, taxpayers may take a more positive view of paying taxes if they have a sense of what the taxes pay for. This means that government programs may rely on dedicated taxes even when there is no natural linkage between the taxes and spending, and even though matching taxes to expenditures is otherwise generally undesirable when one is seeking an efficient public sector.

Beyond the obvious observation that the practice of public finance would be easier (if less interesting) to explain if we were all economists, how should a public finance theorist respond to these conclusions? Some of what we observe may indeed reflect the fact that we are not all economists and may not understand how economic policies work. Unless we undertake a major program of universal economics education, however, and perhaps even if we do so, our theory needs to adapt to this lack of understanding. What we observe also appears to reflect a different way of thinking about fairness and the benefits of public policy, a 
way of thinking that is not easily modeled or described in a logically consistent manner and may not be overcome by one lesson, or several lessons, in economics. Modeling such beliefs is a challenge, but a necessary one to confront if we are to develop public policies that are not only socially beneficial but are also perceived to be so. In short, we have much work to do.

\section{References}

Akerlof, George A. (1978), "The Economics of 'Tagging' as Applied to the Optimal Income Tax, Welfare Programs, and Manpower Planning," American Economic Review 68, 8-19.

Atkinson, Anthony B., and Joseph E. Stiglitz (1976), "The Design of Tax Structure: Direct versus Indirect Taxation,” Journal of Public Economics 6, 55-75.

Auerbach, Alan J. (1993), "Public Finance in Theory and Practice," National Tax Journal 46, 519-26.

Auerbach, Alan J., and Joel Slemrod (1997), "The Economic Effects of the Tax Reform Act of 1986," Journal of Economic Literature 35, 589-632.

Chetty, Raj, Adam Looney, and Kory Kroft (2007), "Salience and Taxation: Theory and Evidence," NBER Working Paper No. 13330, August.

Coate, Stephen, and Stephen Morris (1995), "On the Form of Transfers to Special Interests," Journal of Political Economy 103, 1210-35.

Domar, Evsey D., and Richard A. Musgrave (1944), "Proportional Income Taxation and RiskTaking," Quarterly Journal of Economics 58, 388-422.

European Commission Taxation and Customs Union (2009), VAT Rates Applied in the Member States of the European Community, Brussels.

Feenstra, Robert C. (1992), "How Costly is Protectionism?" Journal of Economic Perspectives 6, 159-78.

Feldstein, Martin S., and Andrew A. Samwick (1992), "Social Security Rules and Marginal Tax Rates," National Tax Journal 45, 1-22.

Graetz, Michael J. (2008), 100 Million Unnecessary Returns: A Simple, Fair, and Competitive Tax Plan for the United States, New Haven: Yale University Press.

Hines, James R., Jr. (2007), “Taxing Consumption and Other Sins," Journal of Economic Perspectives 21, 49-68.

Kaplow, Louis and Steven Shavell (1994), "Why the Legal System is Less Efficient Than the Income Tax in Redistributing Income," Journal of Legal Studies 23, 667-681. 
Krishna, Aradhna, and Joel Slemrod (2003), "Behavioral Public Finance: Tax Design as Price Presentation," International Tax and Public Finance 10, 189-203.

McCaffery, Edward J., and Jonathan Baron (2003), "The Humpty Dumpty Blues:

Disaggregation Bias in the Evaluation of Tax Systems," Organizational Behavior and Human Decision Processes 91, 230-242.

Musgrave, Richard A., and Peggy B. Musgrave (1989), Public Finance in Theory and Practice, $5^{\text {th }}$ ed., New York: McGraw-Hill.

Sah, Raaj Kumar (1983), "How Much Redistribution is Possible through Commodity Taxes?" Journal of Public Economics 20, 89-101.

Tabellini, Guido (2000), “A Positive Theory of Social Security,” Scandinavian Journal of Economics 102, 523-545.

U.S. Office of Management and Budget (2009), A New Era of Responsibility: Renewing America's Promise, Washington, DC: U.S. Government Printing Office. 